\title{
Alarin stimulates food intake in male rats and $\mathrm{LH}$ secretion in castrated male rats
}

\author{
Nicole Van Der Kolka, Farrah N. Madisona ${ }^{\mathrm{a}}$, Margaret Mohra, Nicole Eberhard ${ }^{\mathrm{b}}$, Barbara

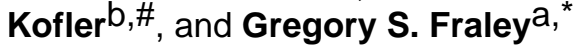 \\ a Department of Biology and Neuroscience Program, Hope College, Holland, MI 49423, USA \\ b Department of Pediatrics, Paracelsus Medical University, A-5020 Salzburg, Austria
}

\section{Abstract}

Alarin is a newly identified member of the galanin family of neuropeptides that includes galaninlike peptide (GALP) and galanin. Alarin was discovered as an alternate transcript of the GALP gene in neuroblastoma cells, and subsequently alarin mRNA was detected in the brain of rodents. GALP and galanin are important central regulators of both feeding and reproductive behavior. We hypothesized, that, as a member of the galanin family of peptides, alarin would also have central effects on feeding and reproduction. To test this hypothesis, we treated male rats with alarin intracerebroventricularly (i.c.v.) and measured its effects on food intake and energy homeostasis as well as sexual behavior and luteinizing hormone (LH) secretion. We observed that i.c.v. injection of $1.0 \mathrm{nmol}$ alarin significantly increased food intake $(\mathrm{p}<0.01)$ and body weight $(\mathrm{p}<$ 0.05 ). Alarin did not affect sexual behavior in male rats; however, alarin did significantly ( $\mathrm{p}<$ 0.01 ) increase LH levels in castrated, but not intact, male rats. Alarin immunoreactive cell bodies were detected within the locus coeruleus and locus subcoeruleus of the midbrain, which is a brainstem nucleus involved in coordinating many physiological activities, including food intake and reproduction. Lastly, alarin stimulated Fos induction in hypothalamic nuclei, such as the paraventricular nucleus and the nucleus of the tractus solitarious. Our studies demonstrate that alarin, like other members of the galanin family, is a neuromediator of food intake and body weight.

\section{Keywords}

alarin; food intake; rat; luteinizing hormone; galanin peptide family

\section{INTRODUCTION}

The galanin family of peptides has an array of pleiotropic functions (Lang et al., 2007). Galanin and its receptors have been isolated from numerous tissues and are found throughout the central nervous system where they are known to regulate multiple physiologic processes, including the hypothalamic-pituitary-gonadal (HPG) axis,

\footnotetext{
*Corresponding author. Address: 35 East $12^{\text {th }}$ Street, SC 3065; Biology Department Hope College, Holland, MI 49423, USA; Tel.: +1 616-395-7306; fax: +1 616-395-7125, fraley@ hope.edu (Gregory S. Fraley). ${ }^{\#}$ To whom correspondence may be addressed at: Address: Department of Pediatrics, Paracelsus Medical University, Muellner Hauptstr. 48, A-5020 Salzburg, Austria Tel.: +43 662 4482 4741; fax: +43662 44824765 (fax), b.kofler@salk.at (Barbara Kofler).

Publisher's Disclaimer: This is a PDF file of an unedited manuscript that has been accepted for publication. As a service to our customers we are providing this early version of the manuscript. The manuscript will undergo copyediting, typesetting, and review of the resulting proof before it is published in its final citable form. Please note that during the production process errors may be discovered which could affect the content, and all legal disclaimers that apply to the journal pertain.
} 
reproductive behaviors, food intake, and energy metabolism (for review see (Gundlach et al., 2001)). Galanin-like peptide (GALP) has also been identified in brain tissue of numerous species and, like galanin, has central actions on energy metabolism and reproduction. Galanin-producing neurons are distributed throughout the central nervous system; however, GALP mRNA is found mainly within the arcuate nucleus (ARC) of the hypothalamus (Ohtaki et al., 1999, Juréus et al., 2000, Larm and Gundlach, 2000, Juréus et al., 2001, Cunningham et al., 2002). Like galanin, GALP is also implicated in regulation of the HPG axis (Matsumoto et al., 2001, Seth et al., 2004, Kauffman et al., 2005, Uenoyama et al., 2008), male sexual behavior (Fraley et al., 2004b, Stoyanovitch et al., 2005), food intake (Lawrence et al., 2002a, Matsumoto et al., 2002, Seth et al., 2002, Krasnow et al., 2003b, Fraley, 2006) and energy metabolism (Rich et al., 2007).

Recently a third member of the galanin peptide family was identified. The new peptide, alarin, was discovered as an alternate transcript of the GALP gene (Santic et al., 2006, Lang et al., 2007, Santic et al., 2007). The alarin transcript excludes exon 3 of the GALP gene, resulting in a frame shift of the GALP mRNA sequence that produces a 25 amino acid alarin peptide. Alarin was first identified in neuroblastoma gangliocytes (Santic et al., 2006). Like galanin, alarin mRNA and alarin-like immunoreactivity have been found in the skin. In accordance with its vascular localization, alarin, in analogy to galanin and GALP (Bauer et al., 2008), inhibits plasma extravasation via a potent vasoconstrictor activity (Santic et al., 2007). In contrast to galanin and GALP in general, the physiological effects of alarin do not appear to be mediated via the known galanin receptors (Santic et al., 2007).

Alarin mRNA has also been identified in rodent brain (Santic et al., 2007); however, its site of expression and the function of alarin within the central nervous system are unknown. The purpose of this study was to determine if alarin has effects on energy homeostasis and reproduction in the male rat and to demonstrate the expression of alarin peptide within the rat brain. We report that alarin peptide is expressed in the hindbrain of the rat and that, like galanin and GALP, alarin alters feeding; but, unlike galanin and GALP, alarin has limited effects on the reproductive system.

\section{Materials and Methods}

\subsection{Animals}

Adult male Long Evans rats (280-300 g) were purchased from Harlan (Indianapolis, IN). Animals were individually housed in microenvironment chambers to prevent crosshormonal influence. They were given a standard rodent diet and water ad libitum. They were kept on a 12:12 light-dark cycle with lights on at $07.00 \mathrm{hr}$. All procedures were approved by the Hope College Animal Care and Use Committee in accordance with the National Institutes of Health Guide for Care and Use of Laboratory animals. All male rats were sexually experienced prior to the start of the experiments.

\subsection{Lateral Ventricle Cannulation}

Rats were anesthetized with a ketamine cocktail $(100 \mathrm{mg} / \mathrm{ml}$ ketamine; $20 \mathrm{mg} / \mathrm{ml}$ xylazine; $10 \mathrm{mg} / \mathrm{ml}$ acepromazine; 5.0:2.5:1.0 ratio, and placed in a stereotaxic frame. A stainless steel 26-gauge cannula (Plastics One, Roanoke, VA) was inserted into the lateral ventricle $(-1.0 \mathrm{~mm}$ midline, $1.0 \mathrm{~mm}$ posterior to Bregma, $\sim 2.5 \mathrm{~mm}$ ventral to dura mater). After surgery, the animals were allowed to recover for one week, during which time they were handled daily. All compounds were administered in a volume of $3 \mu \mathrm{l}$ by a $10-\mu \mathrm{l}$ Hamilton syringe (Hamilton Inc., Reno, NV) attached to polyethylene tubing (id: $0.58 \mathrm{~mm}$; od: 0.96 $\mathrm{mm}$ ) and a 33-gauge stainless steel injection cannula. Cannula placement was verified at the 
end of the experiment by injecting $1 \mu \mathrm{l}$ of blue food-coloring dye prior to sacrifice and inspecting coronal brain slices for proper location of the dye.

\subsection{Radioimmunoassay}

Plasma concentrations of LH were measured at Northwestern University (Evanston, IL), with reagents from the NIH. The LH antiserum was anti-rLH-S11, the standard was rLH$\mathrm{RP} 3$, the assay sensitivity was $0.2 \mathrm{ng} / \mathrm{ml}$, and the intra-assay coefficient of variation was $2.2 \%$.

\subsection{Effect of Alarin on Food Intake and Body Weight}

A common effect of all members of the galanin family of peptides is to increase food intake; thus, we chose this as an initial assessment to determine effective doses of i.c.v. alarin. Adult male Long Evans rats were injected with either $0.1 \mathrm{nmol}, 0.5 \mathrm{nmol}, 1.0 \mathrm{nmol}, 5.0$ nmol rat alarin (1-25)-amide (custom synthesized by GL Biochem, Shanghai, China) in 3.0 $\mu \mathrm{l}$ vehicle $(0.1 \mathrm{M}$ phosphate buffer $(\mathrm{PB}), \mathrm{pH}=7.4)$ or vehicle alone $(\mathrm{n}=10$ per treatment group). Animals were injected on a rotational basis so that all animals received all treatments. All injections were completed between 09.00 and $10.00 \mathrm{hr}$ and subsequent injections were performed at least $72 \mathrm{hr}$ apart. After collecting body weights, rats were injected i.c.v. then placed back in their cages with a known amount of food in the hopper. Food weight, including spillage in the cage, was measured at 30, 60, 120, 180, $240 \mathrm{~min}$ following injections. Food weight and body weights were again measured $24 \mathrm{hr}$ after injections.

\subsection{Effect of Alarin on Oxygen Consumption}

All rats were fully habituated to the metabolic chambers prior to the onset of experiments to measure oxygen consumption. Approximately 1 week after surgery (prior to puberty in either sex), rats ( $\mathrm{n}=8$ per group) were placed in a $13.5 \mathrm{~cm}$ wide, $30.5 \mathrm{~cm}$ long and $21.5 \mathrm{~cm}$ deep plexiglass chamber. Oxygen consumption was utilized as an indirect measure of metabolic rate. Air from the room was drawn through the chambers at $1.3 \mathrm{~L} / \mathrm{min}$ and the oxygen content of the room air was determined by using Amatex S-3A/II. Oxygen consumption was monitored for $1.5 \mathrm{hr}$ with no personnel present in the room. This time frame was chosen based upon the feeding effects observed following i.c.v. alarin (see results). The first $30 \mathrm{~min}$ of each test was not included for analyses, to allow for habituation to the test chamber. After the oxygen consumption test was complete, rats were returned to their cages in the vivarium. Tests were performed between 10.00 and $12.00 \mathrm{hrs}$ during the beginning of the animals' day cycle at a time when the rats would least likely be active or eating. No food was given during the 90 -min test.

\subsection{Effect of Alarin on Male-Typical Sex Behaviors}

Two weeks after i.c.v. injection of alarin for the determination of the effect on food intake, the same male rats were injected with either $1.0 \mathrm{nmol}$ alarin or vehicle $(\mathrm{n}=8-10$ per treatment group) and immediately placed with a steroid-primed female rat as described previously (Fraley et al., 2004b). The dose of alarin was chosen because it was observed to elicit the maximal effect on feeding behaviors. Dosages of other members of the galaninrelated peptides are similar regardless of investigations into feeding or reproductive physiology. Injections were performed so that each rat received all of the treatments. Subsequent injections were carried out at least $72 \mathrm{hr}$ apart. The order of treatments and the testing order were randomized.

Within 5 min following the injection, the rats were placed into a testing arena (polyethylene housing cage) with a sexually-experienced steroid-primed female rat (10 $\mu \mathrm{g}$ estradiol 
benzoate in $0.1 \mathrm{ml}$ safflower oil injected subcutaneously (s.c.) $48 \mathrm{hr}$ prior to testing and 500 $\mu \mathrm{g}$ progesterone in $0.1 \mathrm{ml}$ safflower oil injected s.c. $2 \mathrm{hr}$ prior to testing). The males were scored for the number of mounts, intromissions, and ejaculations and the latency to these behaviors in a 20-min test. A mount was recorded if the male approached the female from the rear and placed both forelegs firmly on her flanks and locked his hips (pelvic thrust alone). An intromission was recorded if the foregoing behavior was noted with the addition of a clear pelvic thrust and penile insertion into the vagina, followed by genital grooming. Ejaculations were scored when ejaculatory typical behaviors were observed following an intromission (Fraley et al., 2004b).

\subsection{Effect of Alarin to Stimulate Luteinizing Hormone Secretion}

A separate set of male rats was injected with either $1.0 \mathrm{nmol}$ alarin or vehicle. This dose was chosen since it was the minimally effective dose that elicited the maximal effects on previous experiments. Male rats were either gonadally intact ( $n=6$ per treatment group) or castrated 3 weeks prior to injections ( $n=8$ per group). Animals were euthanized by decapitation $30 \mathrm{~min}$ following injection. This time course has been shown to be sufficient to demonstrate stimulatory effects on LH secretion by both galanin (Lopez and Negro-Vilar, 1990, Sahu et al., 1994, Finn et al., 2000) and GALP (Matsumoto et al., 2001, Krasnow et al., 2003a).

\subsection{Immunocytochemical Localization of Alarin Peptide}

Immunocytochemistry for alarin peptide was performed on one set of four brain sections by a standard ABC (avidin/biotin complex) reaction, as previously described (Fraley and Kuenzel, 1993, Horowitz et al., 2001, Fraley et al., 2003). Male rats $(n=3)$ were perfused with or without ( $\mathrm{n}=3$ per group) prior treatment with i.c.v. colchicine (50 $\mu \mathrm{g}$ in $5 \mu \mathrm{l} 0.1 \mathrm{M}$ phosphate buffer, $24 \mathrm{hr}$ prior to perfusion). Briefly, all rats-either with or without colchicine pretreatment were-perfused transcardially with $4 \%$ paraformaldehyde in $0.1 \mathrm{M}$ $\mathrm{PB}$, brains removed and static fixed in the same aldehyde fixative for 5 hours. Brains were then transferred to $0.1 \mathrm{M}(\mathrm{PB})$ with $30 \%$ sucrose for $48 \mathrm{hrs}$ for cryoprotection and stored at $-80^{\circ} \mathrm{C}$. Four parallel series of $20-\mu \mathrm{m}$ coronal sections of brain tissue were cut on a sliding microtome (American Optical Company, Buffalo, NY) from the diagonal band of Broca (DBB) through the midbrain beyond the level of the cerebellum, and directly mounted on Superfrost Plus slides (VWR; Chicago, IL).

For immunofluorescent detection, slides were processed using the tyramide-amplification procedure (Stanarius et al., 1997, Stanarius et al., 1999, Toda et al., 1999, Wang et al., 1999, Buki et al., 2000, Bobrow and Moen, 2001). Briefly, the slides were incubated in affinitypurified rabbit anti-alarin (Santic et al., 2007) as primary antibody (1:100 in KPBS with $0.4 \%$ Triton-X) for $24 \mathrm{hr}$ at room temperature. After washing, sections were incubated with a goat anti-rabbit, biotinylated secondary antibody (1:5000 in KPBS, $0.4 \%$ Triton-X, Vector Labs) for $2 \mathrm{hr}$ at room temperature, then washed in KPBS 8 times for 10 min each. Slides were then incubated in ABC solution (Vector Laboratories, in KPBS with $0.4 \%$ Triton-X) for $1 \mathrm{hr}$ at room temperature and again washed in KPBS. Slides were then incubated in biotinylated tyramine $\left(5 \mu \mathrm{l} / \mathrm{ml}\right.$ in $\mathrm{KPBS}$ with $\left.0.005 \% \mathrm{H}_{2} \mathrm{O}_{2}\right)$ for $20 \mathrm{~min}$ at room temp. After washing, slides were incubated in streptavidin-Texas red fluorophore $(5 \mu \mathrm{l} / \mathrm{ml} \mathrm{KPBS}$ with $0.04 \%$ Triton- $\mathrm{X}$ ) for $3 \mathrm{hr}$ at $37^{\circ} \mathrm{C}$. After 810 -min washes in KPBS, slides were coverslipped and analyzed by fluorescent microscopy.

\subsection{Fos Activation Following i.c.v. Injection of Alarin}

A separate set of adult male rats was equipped with cannmulas placed into the lateral ventricle as described above. Rats were injected with either $1.0 \mathrm{nmol}$ alarin or vehicle also as described above ( $\mathrm{n}=4$ per injection). The rats were not allowed access to food or water 
for $2 \mathrm{hr}$ as published previously by our lab (GSF; (Dungan et al., 2007, Taylor et al., 2009). After $2 \mathrm{hr}$, they were anesthetized and perfused transcardially as described above. Tissues were collected from the DBB through the hindbrain in fours sets of $40 \mu \mathrm{m}$ sections. One set of tissue was processed for Fos immunoreactivity (Oncogene; 1:40k) and visualized as described above with Ni-enhanced DAB. Sections were mounted on slides, coverslipped after dehydration in graded ethanols, and analyzed by light microscopy. Fos-positive nuclei were observed as clusters of dark-stained cellular nuclei and compared across treatment groups qualitatively.

\subsection{Statistical Analyses}

Analyses of reproductive behavior data were performed with a Wilcoxon Signed Rank Analysis. All other data were analyzed with an analysis of variance (ANOVA) and a Fisher's PLSD posthoc test. All analyses were performed with GB-Stat Statistical Software (General Dynamics, Inc., Bethesda, MD). A p $<0.05$ was considered significant.

\section{Results}

\subsection{Effect of Alarin on Food Intake, Body Weight and Metabolism}

At the time of ICV injections, there was no significant difference in body weight among treatment groups. A consistent observation of both galanin and GALP is their stimulatory effect on food intake (Kyrkouli et al., 1990, Lawrence et al., 2002b, Matsumoto et al., 2002); thus, we utilized feeding behavior to determine effective doses of alarin. Because galanin peptides have the potential to act at several sites throughout the brain, our studies utilized cannulas placed into the lateral ventricle (i.c.v.). A dose-dependent response was seen when intact male rats received i.c.v. injections of alarin (Fig. 1A). After $30 \mathrm{~min}$, the rats injected with $1.0 \mathrm{nmol}$ and $5 \mathrm{nmol}$ alarin had a significantly higher cumulative food intake than the rats treated with vehicle. After 2,3 and $4 \mathrm{hr}$, the $0.1 \mathrm{nmol}, 0.5 \mathrm{nmol}$, and $1.0 \mathrm{nmol}$ doses produced a significantly increased cumulative food intake The $5.0 \mathrm{nmol}$ dose did not further increase food intake beyond the $1.0 \mathrm{nmol}$ dose. Thus we concluded that the $1.0 \mathrm{nmol}$ dose is the minimal dose that can elicit maximal effects and this dose was utilized for all subsequent experiments. This strategy has been effective for the other members of the galanin peptide family. However, at $24 \mathrm{hr}$ there was no significant difference in cumulative food intake between the different treatments. Interestingly, the $1.0 \mathrm{nmol}$ dose did lead to a significant increase in body weight over the $24 \mathrm{hr}$ period ( $\mathrm{p}<0.01$; Fig 1B), which could not be explained by increased water intake $(\mathrm{p}=0.43)($ Fig. 1C).

Analyses of the metabolic rate revealed a trend that approached significance $(p=0.061)$ for alarin-treated $(1.0 \mathrm{nmol})$ rats, in that they exhibited a lower metabolic rate (as evidenced by oxygen consumption) compared to the vehicle-treated animals (Fig. 2).

\subsection{Effects of Alarin on Male-Typical Sex Behavior and Luteinizing Hormone Secretion}

No significant difference was observed in the numbers of mounts, intromissions, and ejaculations between male rats treated with $1.0 \mathrm{nmol}$ alarin versus vehicle (Fig. 3A). The 1.0 nmol injection had no effect on LH secretion in intact male rats. However, 30 min after injection of $1.0 \mathrm{nmol}$ alarin, a significant $(\mathrm{p}<0.01)$ increase of plasma LH levels was observed in castrated male rats compared to vehicle-treated rats (Fig. 3B).

\subsection{Immunocytochemical Localization of Alarin Peptide}

Staining of sections of the rat hindbrain with an affinity-purified anti-alarin antibody (Santic et al., 2007) revealed alarin-like immunoreactivity (alarin-LI) in cell bodies in the locus coeruleus (LC) and subcoeruleus (LsC). Distribution of alarin-LI was similar in both 
colchicine-treated and -untreated rats. Figure 4 shows representative photomicrographs of alarin immunoreactive cell bodies within the LC.

\subsection{Effect of Alarin on Fos Activation}

Fos activated cells were observed in numerous nuclei throughout the diencephalon and rhombencephalon of male rats injected i.c.v with alarin $(1.0 \mathrm{nmol})$, but not vehicle. Unlike what was reported for either galanin or GALP (for review see (Man and Lawrence, 2008)), no Fos immunoreactivity was observed in alarin-treated male rats in the medial preoptic area (mPOA). A few discrete clusters of Fos-immunoreactive nuclei were observed in hypothalamic nuclei, including the paraventricular nucleus (PVN), dorsomedial nucleus (DMN), and ARC, of alarin-treated but not control male rats. However, the majority of Fosimmunoreactivity was observed in the hindbrain. A dense group of Fos-immunoreactive nuclei was observed within the nucleus of the tractus solitarious (NTS), nucleus prepositus, the dorsal vestibular nucleus and the olive nuclei. See Table 1 for a complete listing of Fos immunoreactivity and Figure 6 for representative photomicrographs of the Fos staining in alarin- and vehicle-treated male rats.

\section{Discussion}

The objectives of this study were, first, to determine if central administration of alarin has similar actions in the rat as other members of the galanin family, and, second, to detect expression of alarin peptide within the rat brain. Our results indicate that, like GALP and galanin, central i.c.v. injection of alarin has effects on both feeding behavior and LH secretion, though alarin's effects appear to be unique and focused primarily on energy homeostasis, rather than on reproduction.

Alarin behaves in a similar way to galanin. Galanin, the original member of this neuropeptide family, also stimulates food intake and slows metabolism (Gundlach et al., 2001). The dose of alarin exerting an effect on feeding is similar to the effective dose of either GALP or galanin (Kyrkouli et al., 1990, Lawrence et al., 2002a, Krasnow et al., 2003b, Kauffman et al., 2005). Loss of activity at higher concentrations, as seen in the present study with a $5 \mathrm{nmol}$ dose of alarin, is a well-known "ceiling" phenomenon in neuropeptide pharmacology. For example, the vascular effects of both galanin and GALP in the periphery exhibit a bell-shaped dose-response curve (Schmidhuber et al., 2007).

Central injections of alarin increased food intake, a finding similar to the action of GALP. GALP is known to have a bimodal effect on feeding behavior in the rat (Matsumoto et al., 2002, Seth et al., 2003, Fraley et al., 2004a). Initially, GALP has an orexigenic effect (Matsumoto et al., 2002) followed by an anorexic effect over a 24-hr period (Fraley et al., 2004a, Stoyanovitch et al., 2005, Taylor et al., 2009). The anorexic effect of GALP is also accompanied by an increase in metabolic rate (oxygen consumption) and body weight (Rich et al., 2007). These observations may be a result of GALP acting on extrahypothalamic sites, as suggested by Fos activation in the NTS (Fraley et al., 2003, Lawrence et al., 2003). Interestingly, our study also demonstrates that i.c.v. injections of alarin increase Fos activity in the NTS and other respiratory centers of the hindbrain (e.g. nPr; (Rollins et al., 2006)). Intracerebroventricular injection of alarin also elicited a trend toward reduced metabolic rate that approached significance. The lack of significance in this effect could be due to the chosen site of injection, the lateral ventricle, if alarin acts principally within the hindbrain. Further studies comparing direct injections of alarin to GALP and galanin into the NTS or other hindbrain nuclei may help elucidate each member's role in the regulation of energy homeostasis. 
Alarin-LI positive cell bodies were observed primarily in the LC, although a few positive cell bodies were also observed in the LsC. The LC is a brainstem nucleus that is involved in the coordination of many basic physiological activities, including food intake (Monnikes et al., 1997, Briski and Marshall, 2000, Ammar et al., 2001) and reproduction (Sar and Stumpf, 1981, Saitoh et al., 1991, Pinos et al., 2001). Hypothalamic peptides responsible for the seeking and ingestion of food have been found to have projections to the LC (Dickinson et al., 2008). Using anterograde tracing, projections have been found from the PVN to the LC. The anatomical localization of alarin in the LC supports the physiologic data obtained from i.c.v. injections of alarin in the present study. The localization of alarin-LI also in the LC of mice indicates that the effect of alarin on metabolism is not species-specific.

Intracerebroventricular injections of galanin significantly reduced male-typical sex behavior in rats, but stimulated male sex behavior when injected directly into the mPOA (Bloch et al., 1993). I.c.v. injection of GALP stimulated Fos in the mPOA and significantly increased male-typical sex behaviors (Fraley et al., 2004b, Stoyanovitch et al., 2005). Interestingly, in the present study, alarin had no effect on male sex behavior or Fos activation within the mPOA. However, alarin, like other members of the galanin neuropeptide family, induces Fos throughout the male rat brain, but it does so in a fashion that is unique to alarin. Alarin appeared to increase Fos expression beyond that of vehicle throughout the diencephalon, including in the septal areas and the PVN. All of these regions have been implicated in various aspects of reproduction and feeding. Strong Fos induction was observed in several hindbrain areas, all regions that regulate physiological homeostasis-including feeding, respiration, and energy metabolism. Thus, alarin may have functions distinct from galanin and GALP in the regulation of homeostatic mechanisms through actions within the hindbrain.

Alarin's effect on LH secretion appears to be steroid-dependant, similar to that of galanin. Central injection of galanin in castrated male rats inhibited LH secretion, but galanin has been shown to stimulate LH release following testosterone replacement (Scheffen et al., 2003). GALP, in male rats, acts independently of sex steroids (Cunningham, 2003), although some evidence shows that estrogen elicits stimulatory effects of GALP on LH secretion in female rats (Uenoyama et al., 2008). Alarin also stimulates LH secretion in male rats but only following castration. A similar steroid-dependent phenomenon has been described with other neuropeptides. For example, neuropeptide Y (NPY) is known to have steroiddependant effects on LH secretion in numerous species (Urban et al., 1993, Li et al., 1994, Leibowitz et al., 1998). The LC, where NPY, and now alarin, have been localized, is implicated in sex differences in feeding behavior and reproduction (Pinos et al., 2001, Pinos et al., 2004).

The partly unique action of alarin compared to the other members of the galanin peptide family might be explained by the fact that alarin most likely does not activate galanin receptors. Santic et al. have shown previously that alarin is not able to acitvate GalR1 and GalR2 receptors. Since alarin does not share any homology to galanin it is also most unlikely that alarin is able to activate GalR3 (Santic et al., 2007). Given the fact that alarin shares only five identical amino acids with GALP it is also unlikely that alarin can activate GALP specific receptors. Since a large number of G-protein-coupled receptors are expressed in the CNS and most neuropeptide receptors are members of the G-protein coupled receptor superfamily, many of them lacking data on a ligand, we hypothesize that alarin receptors also belong to this type of receptor family. However, we cannot exclude the presence of an unknown galanin/GALP receptor, which is also activated by alarin.

The galanin family clearly plays an important role in the central regulation of feeding and energy homeostasis, and, as documented here, alarin is no exception. Alarin is an exciting, 
newly discovered neuropeptide of the galanin peptide family whose central regulatory effects are now beginning to be elucidated.

\section{Acknowledgments}

Grant support:

These studies were supported by NSF REU and Howard Hughes Medical Institute grants to the Biology Department at Hope College, and a grant of the Paracelsus Medical University Salzburg.

\section{References}

Ammar AA, Sodersten P, Johnson AE. Locus coeruleus noradrenergic lesions attenuate intraoral intake. Neuroreport 2001;12:3095-3099. [PubMed: 11568644]

Bauer JW, Lang R, Jakab M, Kofler B. Galanin family of peptides in skin function. Cell Mol Life Sci 2008;65:1820-1825. [PubMed: 18500644]

Bloch GJ, Butler PC, Kohlert JG, Bloch DA. Microinjection of galanin into the medial preoptic nucleus facilitates copulatory behavior in the male rat. Physiol Behav 1993;54:615-624. [PubMed: 7504308]

Bobrow MN, Moen PT Jr. Tyramide signal amplification (TSA) systems for the enhancement of ISH signals in cytogenetics. Curr Protoc Cytom 2001;Chapter 8(Unit 8):9. [PubMed: 18770747]

Briski KP, Marshall ES. Caudal brainstem Fos expression is restricted to periventricular catecholamine neuron-containing loci following intraventricular administration of 2-deoxy-D-glucose. Exp Brain Res 2000;133:547-551. [PubMed: 10985689]

Buki A, Walker SA, Stone JR, Povlishock JT. Novel application of tyramide signal amplification (TSA): ultrastructural visualization of double-labeled immunofluorescent axonal profiles. J Histochem Cytochem 2000;48:153-161. [PubMed: 10653596]

Cunningham, MJ.; Krasnow, SM.; Jureus, A.; Li, D.; Carlson, AE.; Teklemichael, DN.; Clifton, DK.; Steiner, RA. Galanin-like peptide (GALP) as a potential regulator of pituitary hormone secretion. Society for Neuroscience; San Diego, CA: 2002.

Cunningham MJ, Krasnow SM, Gevers EF, Chen P, Thompson CK, Robinson ICAF, Smith MS, Clifton DK, Steiner RA. Regulation of Galanin-Like Peptide Gene Expression By Pituitary Hormones and Their Downstream Targets. J Neuroendocrinol 2003;15:1-9. [PubMed: 12535164]

Dickinson H, Walker DW, Castillo-Melendez M. Onset of feeding at birth--perinatal development of the hypothalamic mechanisms that induce appetite and feeding in the newborn. Neurosci Lett 2008;436:1-6. [PubMed: 18395343]

Dungan, HM.; Lash, R.; Clifton, DK.; Steiner, RA.; Fraley, GS. Phenotypic Analysis of Mice Deficient in Galanin-like Peptide (GALP). San Diego, CA: 2007.

Finn PD, Pau KY, Spies HG, Cunningham MJ, Clifton DK, Steiner RA. Galanin's functional significance in the regulation of the neuroendocrine reproductive axis of the monkey. Neuroendocrinology 2000;71:16-26. [PubMed: 10644895]

Fraley G. Immunolesions of glucoresponsive projections to the arcuate nucleus alter glucoprivicinduced alterations in food intake, luteinizing hormone secretion, and GALP mRNA but not sex behavior in adult male rats. Neuroendocrinology 2006;83:97-105. [PubMed: 16825797]

Fraley GS, Kuenzel WJ. Immunocytochemical and histochemical analyses of gonadotrophin releasing hormone, tyrosine hydroxylase, and cytochrome oxidase reactivity within the hypothalamus of chicks showing early sexual maturation. Histochemistry 1993;99:221-229. [PubMed: 8098325]

Fraley GS, Scarlett JM, Shimada I, Teklemichael DN, Acohido BV, Clifton DK, Steiner RA. Effects of diabetes and insulin on the expression of galanin-like peptide in the hypothalamus of the rat. Diabetes 2004a;53:1237-1242. [PubMed: 15111492]

Fraley GS, Shimada I, Baumgartner JW, Clifton DK, Steiner RA. Differential patterns of Fos induction in the hypothalamus of the rat following central injections of galanin-like peptide and galanin. Endocrinology 2003;144:1143-1146. [PubMed: 12639894] 
Fraley GS, Thomas-Smith SE, Acohido BV, Steiner RA, Clifton DK. Stimulation of sexual behavior in the male rat by galanin-like peptide. Hormones and Behavior 2004b;46:551-557. [PubMed: 15555496]

Gundlach AL, Burazin TC, Larm JA. Distribution, regulation and role of hypothalamic galanin systems: renewed interest in a pleiotropic peptide family. Clin Exp Pharmacol Physiol 2001;28:100-105. [PubMed: 11153523]

Horowitz JM, Vernace VA, Myers J, Stachowiak MK, Hanlon DW, Fraley GS, Torres G. Immunodetection of Parkin protein in vertebrate and invertebrate brains: a comparative study using specific antibodies. J Chem Neuroanat 2001;21:75-93. [PubMed: 11173222]

Juréus A, Cunningham MJ, Li D, Johnson LL, Krasnow SM, Teklemichael DN, Clifton DK, Steiner RA. Distribution and regulation of galanin-like peptide (GALP) in the hypothalamus of the mouse. Endocrinology 2001;142:5140-5144. [PubMed: 11713207]

Juréus A, Cunningham MJ, McClain ME, Clifton DK, Steiner RA. Galanin-like peptide (GALP) is a target for regulation by leptin in the hypothalamus of the rat. Endocrinology 2000;141:2703-2706. [PubMed: 10875277]

Kauffman AS, Buenzle J, Fraley GS, Rissman EF. Effects of galanin-like peptide (GALP) on locomotion, reproduction, and body weight in female and male mice. Horm Behav 2005;48:141151. [PubMed: 16042964]

Krasnow SM, Fraley GS, Schuh SM, Baumgartner JW, Clifton DK, Steiner RA. A role for galaninlike peptide (GALP) in the integration of feeding, body weight regulation and reproduction in the mouse. Endocrinology 2003a;144:813-822. [PubMed: 12586757]

Krasnow SM, Fraley GS, Schuh SM, Baumgartner JW, Clifton DK, Steiner RA. A role for galaninlike peptide in the integration of feeding, body weight regulation, and reproduction in the mouse. Endocrinology 2003b;144:813-822. [PubMed: 12586757]

Kyrkouli SE, Stanley BG, Seirafi RD, Leibowitz SF. Stimulation of feeding by galanin: anatomical localization and behavioral specificity of this peptide's effects in the brain. Peptides 1990;11:9951001. [PubMed: 1704616]

Lang R, Gundlach AL, Kofler B. The galanin peptide family: receptor pharmacology, pleiotropic biological actions, and implications in health and disease. Pharmacol Ther 2007;115:177-207. [PubMed: 17604107]

Larm JA, Gundlach AL. Galanin-like peptide (GALP) mRNA expression is restricted to arcuate nucleus of hypothalamus in adult male rat brain. Neuroendocrinology 2000;72:67-71. [PubMed: 10971141]

Lawrence CB, Baudoin FM, Luckman SM. Centrally administered galanin-like peptide modifies food intake in the rat: a comparison with galanin. J Neuroendocrinol 2002a;14:853-860. [PubMed: 12421338]

Lawrence CB, Snape AC, Baudoin FM, Luckman SM. Acute central ghrelin and GH secretagogues induce feeding and activate brain appetite centers. Endocrinology 2002b;143:155-162. [PubMed: 11751604]

Lawrence CB, Williams T, Luckman SM. Intracerebroventricular galanin-like peptide induces different brain activation compared with galanin. Endocrinology 2003;144:3977-3984. [PubMed: 12933672]

Leibowitz SF, Akabayashi A, Alexander JT, Wang J. Gonadal steroids and hypothalamic galanin and neuropeptide Y: role in eating behavior and body weight control in female rats. Endocrinology 1998;139:1771-1780. [PubMed: 9528961]

Li S, Hong M, Fournier A, St-Pierre S, Pelletier G. Role of neuropeptide Y in the regulation of gonadotropin-releasing hormone gene expression in the rat preoptic area. Brain Res Mol Brain Res 1994;26:69-73. [PubMed: 7854068]

Lopez FJ, Negro-Vilar A. Galanin stimulates luteinizing hormone-releasing hormone secretion from arcuate nucleus-median eminence fragments in vitro: involvement of an alpha-adrenergic mechanism. Endocrinology 1990;127:2431-2436. [PubMed: 1699747]

Man PS, Lawrence CB. Galanin-like peptide: a role in the homeostatic regulation of energy balance? Neuropharmacology 2008;55:1-7. [PubMed: 18538801] 
Matsumoto H, Noguchi J, Takatsu Y, Horikoshi Y, Kumano S, Ohtaki T, Kitada C, Itoh T, Onda H, Nishimura O, Fujino M. Stimulation effect of galanin-like peptide (GALP) on luteinizing hormone-releasing hormone-mediated luteinizing hormone (LH) secretion in male rats. Endocrinology 2001;142:3693-3696. [PubMed: 11459819]

Matsumoto Y, Watanabe T, Adachi Y, Itoh T, Ohtaki T, Onda H, Kurokawa T, Nishimura O, Fujino M. Galanin-like peptide stimulates food intake in the rat. Neurosci Lett 2002;322:67-69. [PubMed: 11958845]

Monnikes H, Lauer G, Bauer C, Tebbe J, Zittel TT, Arnold R. Pathways of Fos expression in locus ceruleus, dorsal vagal complex, and PVN in response to intestinal lipid. Am J Physiol 1997;273:R2059-2071. [PubMed: 9435662]

Ohtaki T, Kumano S, Ishibashi Y, Ogi K, Matsui H, Harada M, Kitada C, Kurokawa T, Onda H, Fujino M. Isolation and cDNA cloning of a novel galanin-like peptide (GALP) from porcine hypothalamus. J Biol Chem 1999;274:37041-37045. [PubMed: 10601261]

Pinos H, Collado P, Rodriguez-Zafra M, Rodriguez C, Segovia S, Guillamon A. The development of sex differences in the locus coeruleus of the rat. Brain Res Bull 2001;56:73-78. [PubMed: 11604252]

Pinos H, Collado P, Salas M, Perez-Torrero E. Undernutrition and food rehabilitation effects on the locus coeruleus in the rat. Neuroreport 2004;15:1417-1420. [PubMed: 15194865]

Rich N, Reyes P, Reap L, Goswami R, Fraley GS. Sex differences in the effect of prepubertal GALP infusion on growth, metabolism and LH secretion. Physiol Behav 2007;92:814-823. [PubMed: 17632189]

Rollins BL, Stines SG, King BM. Role of the stria terminalis in food intake and body weight in rats. Physiol Behav 2006;89:139-145. [PubMed: 16842829]

Sahu A, Xu B, Kalra SP. Role of galanin in stimulation of pituitary luteinizing hormone secretion as revealed by a specific receptor antagonist, galantide. Endocrinology 1994;134:529-536. [PubMed: 7507825]

Saitoh Y, Silverman AJ, Gibson MJ. Norepinephrine neurons in mouse locus coeruleus express c-fos protein after N-methyl-D,L-aspartic acid (NMDA) treatment: relation to LH release. Brain Res 1991;561:11-19. [PubMed: 1686742]

Santic R, Fenninger K, Graf K, Schneider R, Hauser-Kronberger C, Schilling FH, Kogner P, Ratschek M, Jones N, Sperl W, Kofler B. Gangliocytes in neuroblastic tumors express alarin, a novel peptide derived by differential splicing of the galanin-like peptide gene. J Mol Neurosci 2006;29:145-152. [PubMed: 16954604]

Santic R, Schmidhuber SM, Lang R, Rauch I, Voglas E, Eberhard N, Bauer JW, Brain SD, Kofler B. Alarin is a vasoactive peptide. Proc Natl Acad Sci U S A 2007;104:10217-10222. [PubMed: 17535903]

Sar M, Stumpf WE. Central noradrenergic neurones concentrate 3H-oestradiol. Nature 1981;289:500502. [PubMed: 7464918]

Scheffen JR, Splett CL, Desotelle JA, Bauer-Dantoin AC. Testosterone-dependent effects of galanin on pituitary luteinizing hormone secretion in male rats. Biol Reprod 2003;68:363-369. [PubMed: 12533397]

Schmidhuber SM, Santic R, Tam CW, Bauer JW, Kofler B, Brain SD. Galanin-Like Peptides Exert Potent Vasoactive Functions In Vivo. J Invest Dermatol 2007;127:716-721. [PubMed: 17024098]

Seth A, Stanley S, Dhillo W, Murphy K, Ghatei M, Bloom S. Effects of galanin-like peptide on food intake and the hypothalamo-pituitary-thyroid axis. Neuroendocrinology 2003;77:125-131. [PubMed: 12624534]

Seth A, Stanley S, Jethwa P, Gardiner J, Ghatei M, Bloom S. Galanin-like peptide stimulates the release of gonadotropin-releasing hormone in vitro and may mediate the effects of leptin on the hypothalamo-pituitary-gonadal axis. Endocrinology 2004;145:743-750. [PubMed: 14576185]

Seth A, Stanley SA, Dhillo W, Murphy KG, Bloom SR. The novel hypothalamic peptide Galanin-Like Peptide (GALP) stimulates food intake in male wistar rats. Endocrine Abstracts 2002;2:OC17.

Stanarius A, Faber-Zuschratter H, Topel I, Schulz S, Wolf G. Tyramide signal amplification in brain immunocytochemistry: adaptation to electron microscopy. J Neurosci Methods 1999;88:55-61. [PubMed: 10379579] 
Stanarius A, Topel I, Schulz S, Noack H, Wolf G. Immunocytochemistry of endothelial nitric oxide synthase in the rat brain: a light and electron microscopical study using the tyramide signal amplification technique. Acta Histochem 1997;99:411-429. [PubMed: 9429601]

Stoyanovitch AG, Johnson MA, Clifton DK, Steiner RA, Fraley GS. Galanin-like peptide rescues reproductive function in the diabetic rat. Diabetes 2005;54:2471-2476. [PubMed: 16046316]

Taylor A, Madison FN, Fraley GS. Galanin-like peptide stimulates feeding and sexual behaviors via dopaminergic fibers within the medial preoptic area of adult male rats. Journal of Chemical Neuroanatomy 2009;37:105-111. [PubMed: 19124073]

Toda Y, Kono K, Abiru H, Kokuryo K, Endo M, Yaegashi H, Fukumoto M. Application of tyramide signal amplification system to immunohistochemistry: a potent method to localize antigens that are not detectable by ordinary method. Pathol Int 1999;49:479-483. [PubMed: 10417696]

Uenoyama Y, Tsukamura H, Kinoshita M, Yamada S, Iwata K, Pheng V, Sajapitak S, Sakakibara M, Ohtaki T, Matsumoto H, Maeda KI. Oestrogen-dependent stimulation of luteinising hormone release by galanin-like peptide in female rats. J Neuroendocrinol 2008;20:626-631. [PubMed: 18363811]

Urban JH, Bauer-Dantoin AC, Levine JE. Neuropeptide Y gene expression in the arcuate nucleus: sexual dimorphism and modulation by testosterone. Endocrinology 1993;132:139-145. [PubMed: 8419120]

Wang G, Achim CL, Hamilton RL, Wiley CA, Soontornniyomkij V. Tyramide signal amplification method in multiple-label immunofluorescence confocal microscopy. Methods 1999;18:459-464. [PubMed: 10491275] 

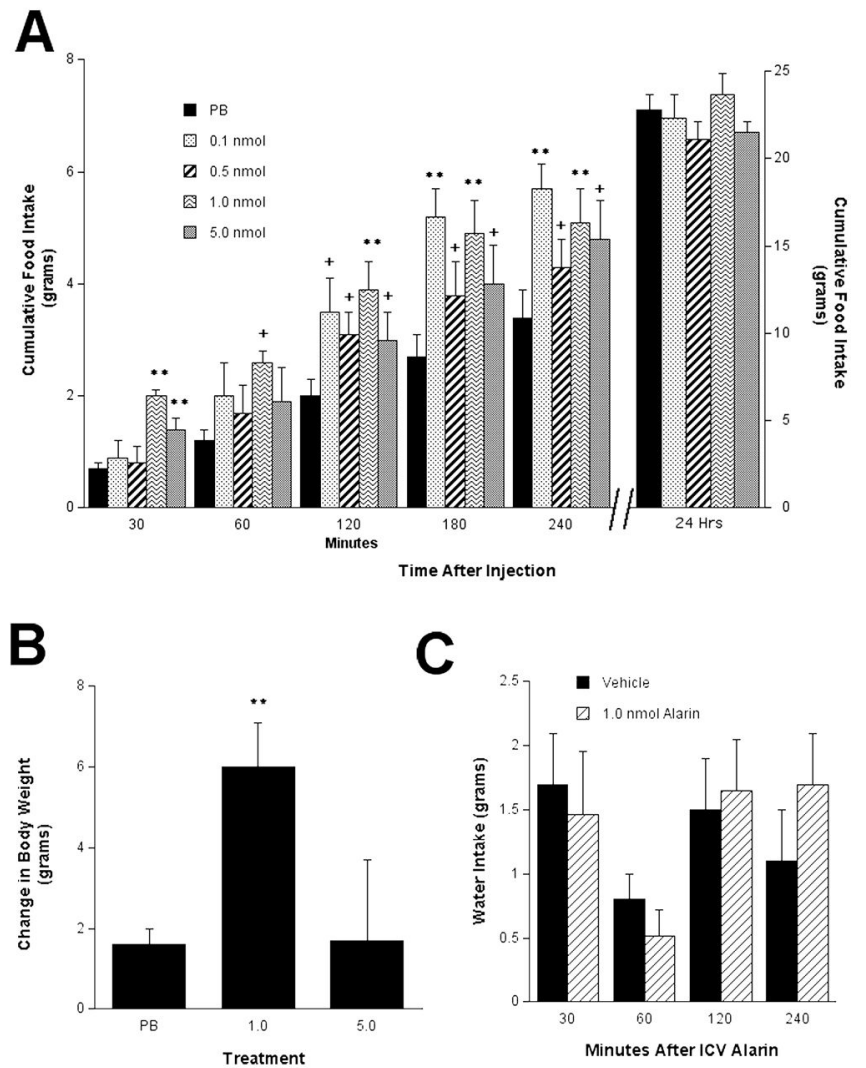

Fig. 1.

I.c.v. injection of alarin elicited a significant increase in food intake that lasted approximately 4 hours but was lost at 24 hours (A). This orexigenic effect of i.c.v. injection of alarin showed a dose responsive pattern. (B) I.c.v. injection of $1.0 \mathrm{nmol}$ alarin did significantly change body weight after 24 hours. (C) I.c.v. injection of alarin had no effect on water intake at any time point. ${ }^{*} * \mathrm{P}<0.01,{ }^{+} \mathrm{P}<0.05$ compared to vehicle control. 


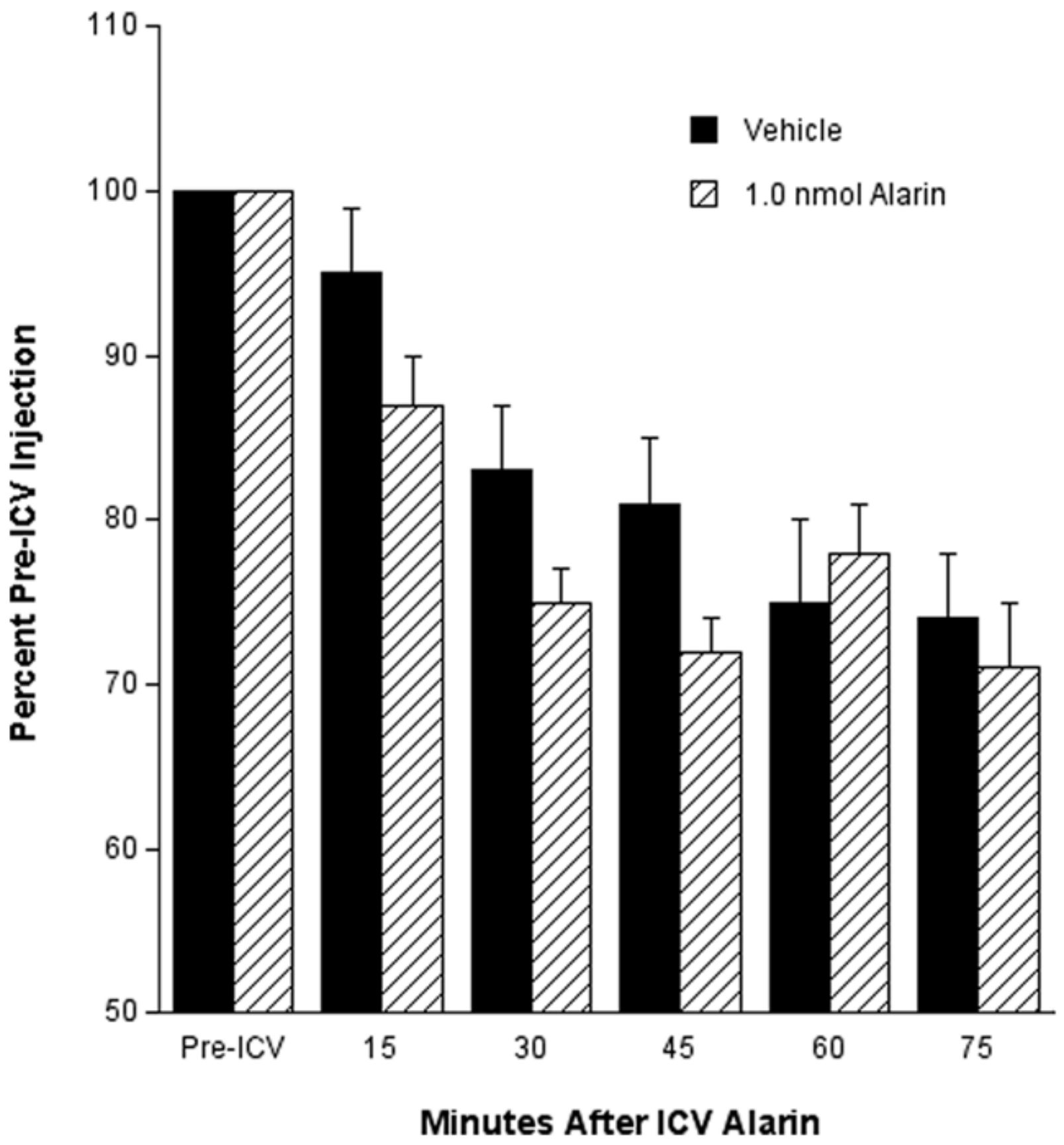

Fig. 2.

Effect of i.c.v. injection of alarin on oxygen consumption (an indirect measure of metabolic rate) relative to vehicle and pre-injection conditions ( $\mathrm{P}=0.06$ at 15,30 , and $45 \mathrm{~min})$. 

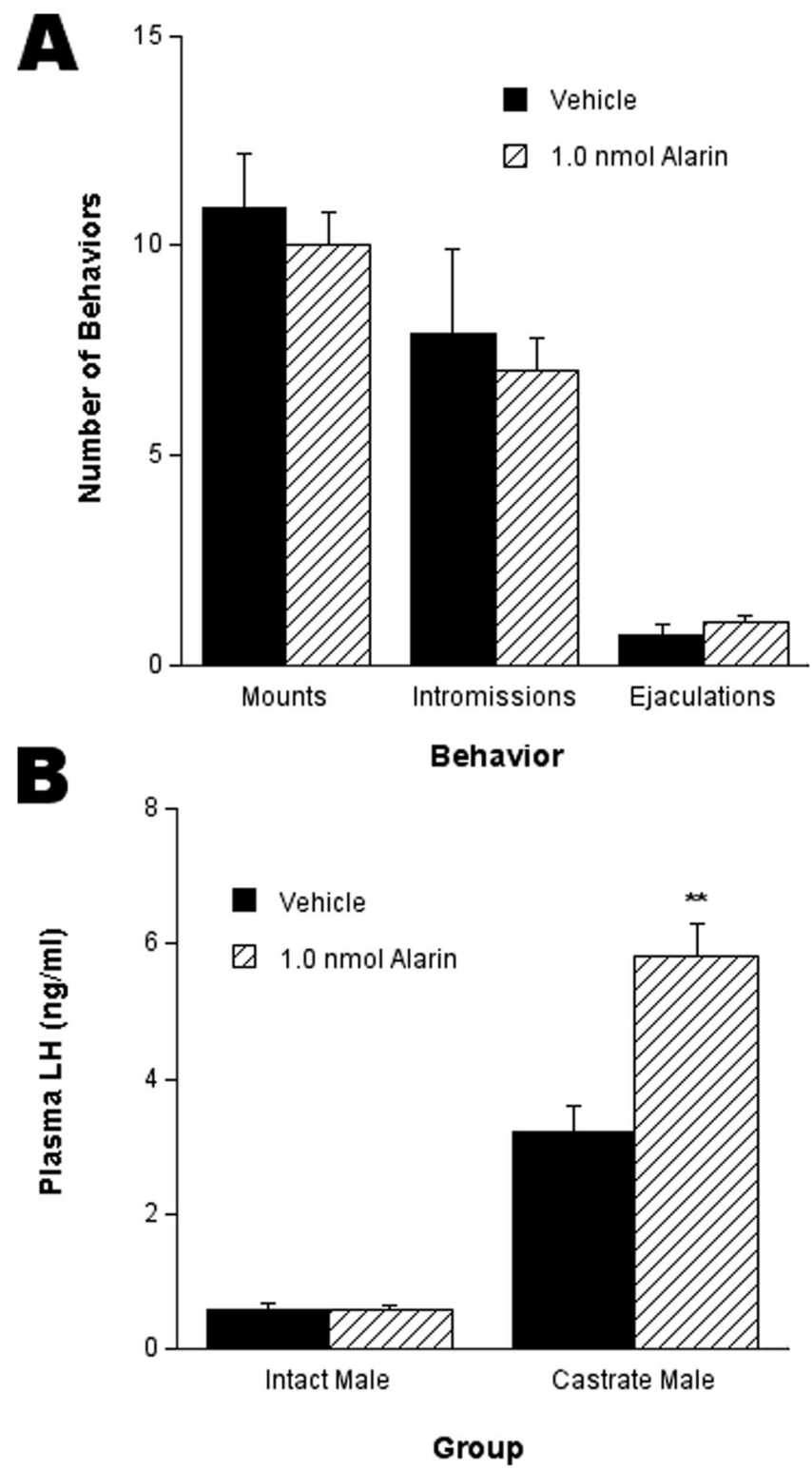

Fig. 3.

I.c.v. injection of alarin had no effect on male-typical sex behaviors in the rat (A). (B) I.c.v. injection of alarin had no effect on plasma LH levels in the intact male rat; however, I.c.v. injection of alarin did elicit a significant increase in plasma LH levels compared to vehicle in castrated male rats. $* * \mathrm{P}<0.01$. 

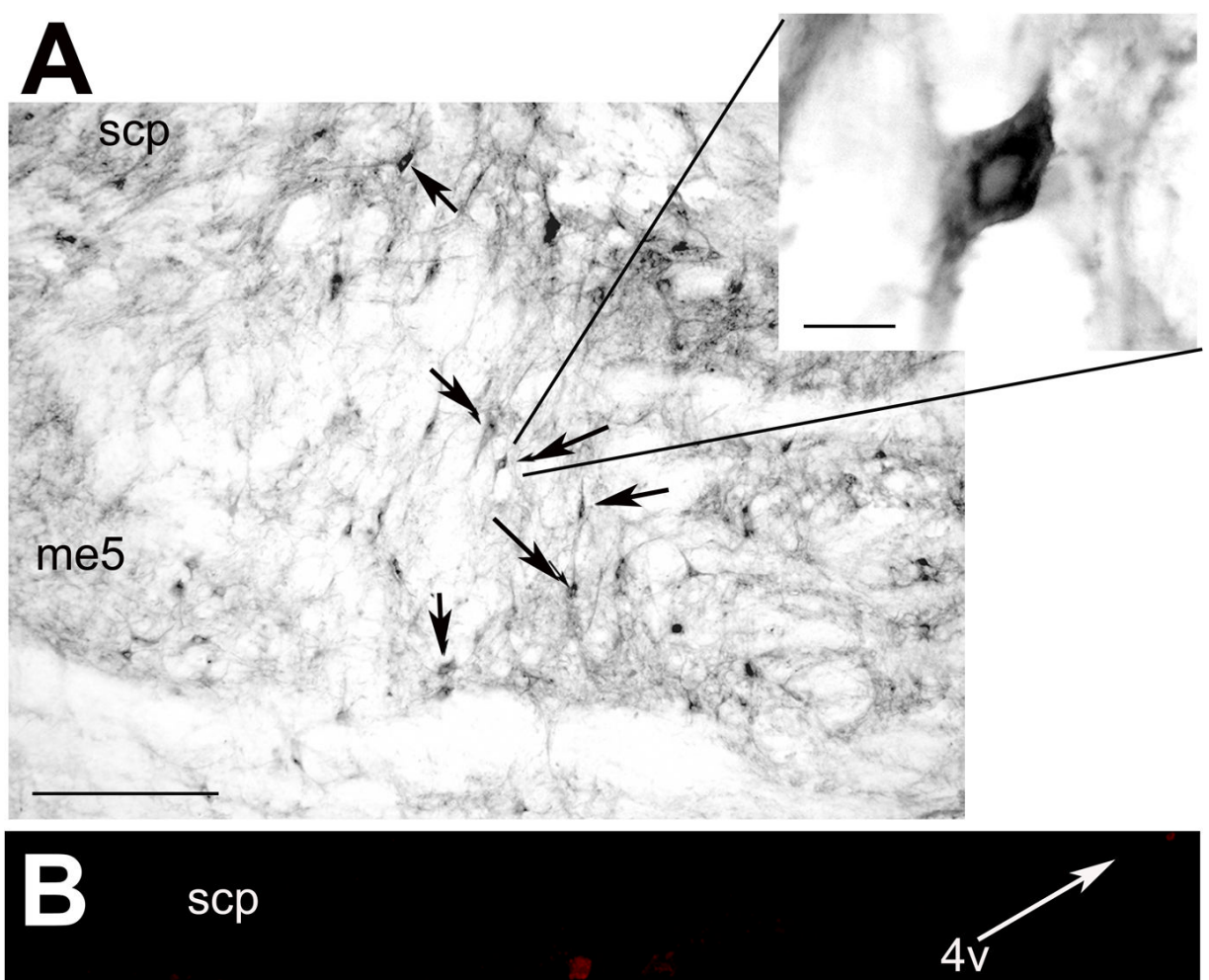

me5

Fig. 4.

Representative photomicrographs illustrating alarin immunoreactive cell bodies within the LC (note the clear nuclei) detected by light microscopy $(\mathrm{A})$ and immunoflourescence, bar = $75 \mu \mathrm{m}$ (B). Arrows indicate alarin-immunoreactive neurons, bar $=50 \mu \mathrm{m} .4 \mathrm{~V}=$ Arrow indicates direction of fourth ventricle; me $5=$ mesencephalic trigeminal tract; $\mathrm{scp}=$ superior cerebellar peduncle. 


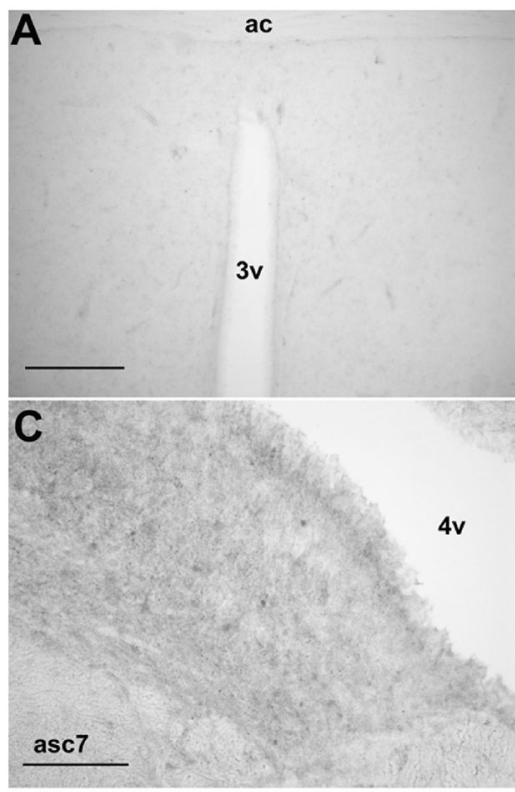

B ac

E
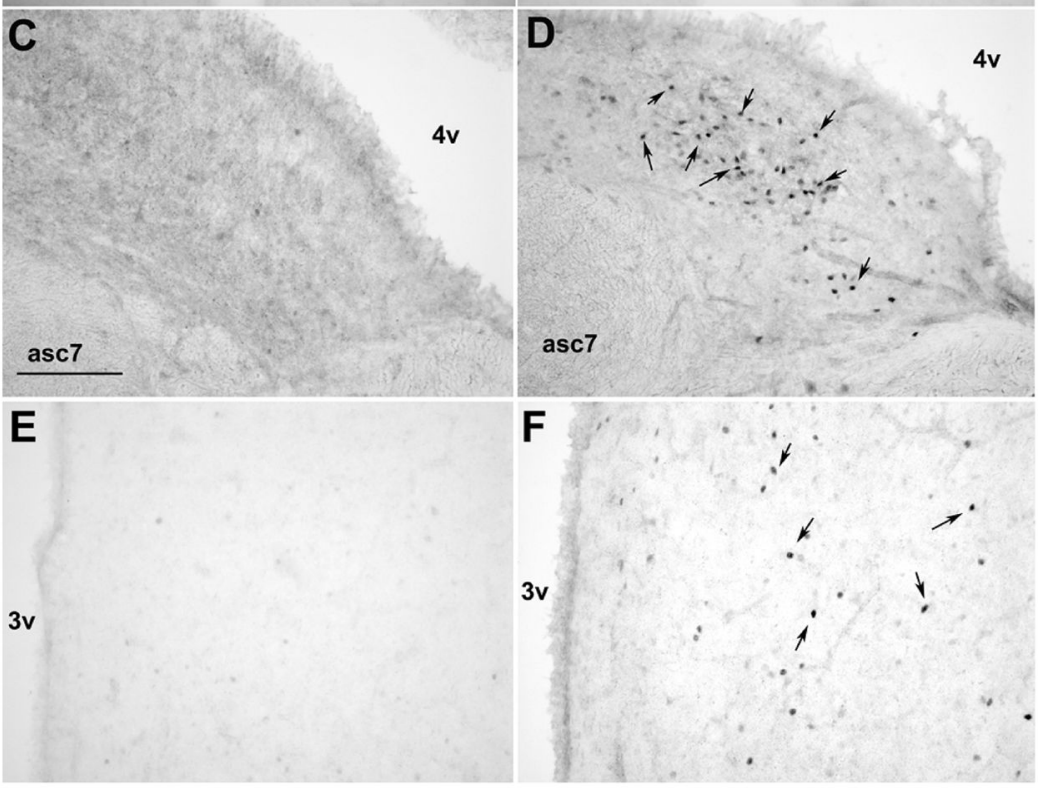

F

$3 v$

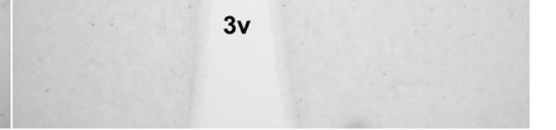

$4 v$

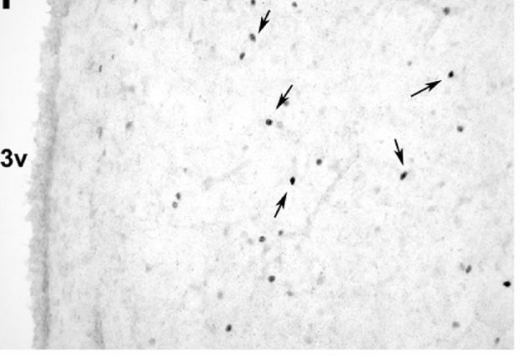

Fig. 5.

Representative photomicrographs of Fos immunoreactive neurons following i.c.v. injection of vehicle (A, C, E) or of $1.0 \mathrm{nmol}$ alarin (B, D, F). (A, B) Little to no fos immunoreactive nuclei were observed following vehicle or alarin in the male rat. $\mathrm{Bar}=150 \mu \mathrm{m}, 3 \mathrm{v}=$ third ventricle, ac = anterior commisure. $(\mathrm{C}, \mathrm{D})$ A dense concentration of fos immunoreactive nuclei were observed in the nucleus prepositus following alarin but not vehicle injections. Bar $=50 \mu \mathrm{m}, 4 \mathrm{v}=$ fourth ventricle, asc7 = ascending fibers of fascial nucleus. (E, F) A few fos immunoreactive nuclei were observed in the hypothalamic paraventricular nucleus follow alarin but no fos was observed following vehicle injections. $3 \mathrm{v}=$ third ventricle. 
Table 1

Distribution of Fos-immunoreactive Nuclei in the Male Rat Brain Injected with Alarin or Vehicle.

\begin{tabular}{lcc}
\hline Structure & Alarin-induced Fos-ir & Vehicle-induced Fos-ir \\
\hline Diencephalon & + & - \\
Medial preoptic nucleus & + & - \\
Diagonal band of Broca & ++ & - \\
Paraventricular nucleus & - & - \\
Ventromedial nucleus & ++ & - \\
Lateral hypothalamus & - & - \\
Median eminence & - & - \\
Periventricular hypothalamic nucleus & ++ & - \\
Dorsomedial nucleus & ++ & - \\
Medial septal nucleus & + & - \\
Lateral septal nucleus & +++ & - \\
Thalamic paraventricular nucleus & & \\
Extra-Diencephalic Structures & + & + \\
Central Gray & +++ & + \\
Raphe nuclei & + & - \\
Locus Coeruleous & +++ & - \\
Nucleus prepositus & + & - \\
Dorsal vestibular nucleus & +++ & ++ \\
Olive nuclei & +++ & \\
Dorsal motor nucleus of Vagus & & + \\
\hline
\end{tabular}

